\title{
Correction to: Establishment of a long-term lake-surface temperature dataset within the European Alps extending back to 1880
}

\author{
Christoph Matulla $^{1} \cdot$ János Tordai $^{1} \cdot$ Matthias Schlögl $^{1,2} \cdot$ Manfred Ganekind $^{3} \cdot$ Herbert Matulla $^{4} \cdot$ Hans RessI $^{1,5}$. \\ Barbara Chimani ${ }^{3}$
}

Published online: 13 December 2018

(c) The Author(s) 2018

\section{Correction to: Climate Dynamics \\ https://doi.org/10.1007/s00382-018-4479-6}

Due to an administrative error the incorrect, unrevised version of this paper has appeared online initially and for some time. The original article has now been corrected.
Open Access This article is distributed under the terms of the Creative Commons Attribution 4.0 International License (http://creativeco mmons.org/licenses/by/4.0/), which permits unrestricted use, distribution, and reproduction in any medium, provided you give appropriate credit to the original author(s) and the source, provide a link to the Creative Commons license, and indicate if changes were made.

The original article can be found online at https://doi.org/10.1007/ s00382-018-4479-6.

Christoph Matulla

christoph.matulla@zamg.ac.at

1 Climate Impact Team, Climate Research Branch,

Zentralanstalt für Meteorologie und Geodynamik, Vienna, Austria

2 Institute of Applied Statistics and Computing, University of Natural Resources and Life Sciences, Vienna, Austria

3 Climate Monitoring Team, Climate Research Branch, Zentralanstalt für Meteorologie und Geodynamik, Vienna, Austria

4 Technical High School for Chemistry, Vienna, Austria

5 Institute for Meteorology and Geophysics, University of Vienna, Vienna, Austria 